\title{
Galilea en Jerusalem as narratologiese ruimtes in die Markusevangelie: 'n Kontinuering van die Lohmeyer- Lightfoot-Marxsen ketting
}

\author{
E van Eck
}

\begin{abstract}
Galilee and Jerusalem as narratological toponyms in the Gospel of Mark: A continuation of the Lohmeyer-Lightfoot-Marxsen chain.

By means of a narratological examination of the Gospel of Mark the role of the toponyms Galilee and Jerusalem as localities of interest is pointed out. It is argued that as such they are important conveyers of the ideological perspective of the narrator. The article furthermore enters into the debate surrounding the redaktionsgeschichtliche contribution of Willi Marxsen on this topic. A narratological examination of the Gospel of Mark reveals further links in the Lohmeyer-Lightfoot-Marxsen chain of thought, although at times correctives are suggested.
\end{abstract}

\section{INLEIDING}

Die tese van die onderhawige artikel is dat 'n literatuurteoretiese ondersoek (met spesiale verwysing na die narratologie) van die Markusevangelie aantoon dat die funksie van die plekname Galilea en Jerusalem in die Evangelie dié is van belangeruimte en so gesien moet word as ' $n$ belangrike draer van die ideologiese perspektief van die redaktor-verteller. Terselfdertyd word daar ook aan die debat deelgeneem oor wat Willi Marxsen se redaktionsgeschichtliche bydrae in hierdie verband is. Vanuit 'n narratologiese perspektief word dikwels beweer dat Marxsen se siening in verband met die teologiese funksie van Galilea en Jerusalem in die Markusevangelie, wat ' $n$ voortsetting is van die standpunte van Lohmeyer en Lightfoot, nie kan opgaan nie. Ons gaan hier poog om aan te toon dat die Lohmeyer-LightfootMarxsen ketting egter wel deur 'n narratologiese ondersoek van die Markusevangelie gekontinueer word. 'n Aantal korrektiewe word in 'n 
sekere sin egter wel met betrekking tot hierdie ketting deur ons voorgestel.

\section{PROGRAM VAN ONDERSOEK}

Om die tese te beredeneer, val die studie in die volgende dele uiteen: Eerstens word die tese van Marxsen in afdeling drie kortliks uiteengesit. Tweedens word in afdeling vier ' $n$ narratologiese evaluering van Marxsen se standpunt gegee deur te kyk na 'n aantal studies wat Galilea en Jerusalem as belangeruimte in die Markusevangelie narratologies probeer verantwoord het: Hier sal onder andere gekyk word na die standpunte van David Rhoads en Donald Michie (afdeling 4.1), Bas van Iersel (afdeling 4.2), Elizabeth Malbon (afdeling 4.3), Willem Vorster (afdeling 4.4) en Norman Petersen (afdeling 4.5). Die resultate van die ondersoek word dan kortliks geëvalueer en daar word laastens volstaan met ' $n$ aantal slotopmerkings.

\section{DIE TOPOGRAFIESE STRUKTUUR VAN DIE MARKUSEVANGELIE}

\subsection{Die Lohmeyer-Lightfoot-Marxsen-Kelber ketting}

Voordat daar spesifiek gekyk word na die bydrae van Marxsen ten opsigte van bogenoemde saak, sal dit goed wees om die geskiedenis van hierdie ondersoek na te gaan. Die bedoeling is om hiermee aan te toon wat die posisie en standpunt van Marxsen self is.

Lohmeyer het in sy werk Galiläa und Jerusalem (1936) die eerste keer aangetoon dat die plekname Galilea en Jerusalem in die Markusevangelie meer as net geografiese 'betekenis' het. Hy meen dat die vroeë Christendom in Palestina twee hoofsentra gehad het, naamlik Galilea en Jerusalem. In Galilea het 'n baie sterk Menseseun-eskatologie voorgekom en in Jerusalem het die klem hoofsaaklik geval op 'n sterk nasionalistiese messiaanse hoop. Beide historiese/geografiese sentra kan dus volgens Lohmeyer 'teologies' beskryf word, en wel in 'n Christologiese sin: Die Christologiese titel Kurios lēsous (d w s Jesus is die Here) word met Galilea gekoppel en die titel Christos Iêsous (d w s Jesus is die Messias) met Jerusalem.

Die Markusevangelie, beweer Lohmeyer, reflekteer die oortuiginge van die Galilese gemeente en hy lê veral klem op Markus 14: 28 ('Maar 
nadat Ek uit die dood opgewek is sal Ek julle vooruit gaan na Galilea toe') en Markus 16: 7 ('Maar gaan sê vir die dissipels en in besonder vir Petrus: Hy gaan julle vooruit na Galilea toe. Daar sal julle Hom sien soos Hy vir julle gesê het.') Waar Galilea dus die plek verteenwoordig van die goddelike openbaring van die wederkoms van die eskatologiese Menseseun (as die begin van die verwagte paroesie), die sentrum van die bediening van Christus en die toekomstige sentrum van die realiserende Koninkryk van God, daar verteenwoordig Jerusalem die opposisie van Jesus in die Markusevangelie. Die volgende aanhaling som hierdie standpunt van Lohmeyer deeglik op en dien terselfdertyd vir ons as die basiese vertrekpunt vir ons Galilea-Jerusalem studie in Markus:

Ich habe in meiner Galiläa und Jerusalem ausgeführe, das für die älteste Christenheit Galiläa die erkorene Stätte, eschatologischer Vollendung geweren ist ... . Sie vertuft und weitert sich der erste, scheinbar nur geografische Gegensatz: dort die überlieferte Heiligkeit des Kultus zu Jerusalem, hier die eschatologisch begrundete Heiligkeit in Galiläa ... (Lohmeyer 1936: 106).

Lightfoot (1938) het vervolgens bogenoemde tesis van Lohmeyer opgeneem deur dit toe te pas op die probleem van die einde van Markus (Mark 16: 8 of Mark 16: 20). Op grond van vorm (literêr en filologies) en inhoud (teologies) beweer hy dat die Evangelie wel by 16: 8 eindig. Volgens hom word dit die duidelikste,aangetoon deur die teenstelling tussen Galilea en Jerusalem soos deur Lohmeyer aangetoon:

Galilee en Jerusalem therefore stand in opposition to each other, as the story of the Gospel runs in St Mark. The despised and more or less outlawed Galilee is shewn to have been chosen by God as the seat of the Gospel and of the revelation of the Son of Man, while the sacred city of Jerusalem, the home of Jewish piety and patronism has become the centre of relentless hostility and sin. Galilee is the sphere of revelation, Jerusalem the scene of rejection. Galilee is the scene of the beginning and middle of the Lord's ministry, Jerusalem only of its end (Lightfoot 1938: 124).

Bogenoemde is die stand van die bespreking in hierdie verband wanneer Marxsen se boek, Der Evangelist Markus, in 1959 verskyn. Sy siening sal vervolgens bespreek word. Alhoewel Kelber met sy boek The Kingdom of Mark, wat in 1974 verskyn het, in werklikheid hierdie 
diskussie voortsit, beperk ons onsself in die onderhawige artikel tot 'n evaluering van die standpunt van Marxsen.

\subsection{Willi Marxsen se 'redaktionsgeschichtliche' benadering}

\subsubsection{Inleiding}

In sy boek Der Evangelist Markus: Studien zur Redaktionsgeschichte der Evangelium wat in 1959 verskyn het, is dit baie duidelik dat Marxsen die klem wat Lohmeyer en Lightfoot gelê het op die historiese en eskatologiese 'betekenis' van Galilea en Jerusalem in die Markusevangelie, aanvaar. Hy verskil egter van hulle daarin dat hy meen dat 'n redaktionsgeschichtliche benadering tot die Evangelie hierdie probleem beter te berde kan bring. Deur redaksie en tradisie in Markus van mekaar te skei (met die klem op die redaksie), word dit duidelik dat die Markusevangelie se raamwerk inhoudelik teologies van aard is en deur 'n uitwendige geografiese raamwerk uitgedruk word. Die sentrum van hierdie teologies-geografiese raamwerk is Galilea, wat enersyds die sentrum van die Markaanse Jesus is, maar andersyds ook dié van die Markaanse gemeente.

Op grond van onder andere Markus 14: 28 en Markus 16: 7, waar die paroesie met die pleknaam Galilea verbind word, is Marxsen van mening dat Markus sy evangelie geskryf het, enersyds vanuit 'n nabye paroesieverwagting en andersyds vanuit die gesigshoek dat die paroesie in Galilea verwag is. Die pleknaam Galilea weerspieël dus iets van die Sitz-im-Leben Ecclesiae van die Markus-gemeente, naamlik die sterk paroesieverwagting (Van Aarde 1982: 128). Marxsen (1959: 71) verwys in hierdie verband na die auf die Parusie wartende Gemeinde in Galiläa und zur Parusie nach Galiläa ziehende Gemeinde. Markus skryf dus hiervolgens 'n 'Galilean Gospel' (Marxsen 1969: 66). Galilea is die tuiste van Jesus, maar meer as net in die sin van bloot as historiese en geografiese lokaliteitsaanduiding. Dit is die plek waar Hy gewerk het, waar sy gemeente hom bevind, en waar Hy by sy paroesie sal werk (vgl Malbon 1982: 245). Galilea dra dus deur en deur teologiese betekenis in die Evangelie.

Wanneer Marxsen bogenoemde idees uitwerk, plaas hy dan ook swaar klem op Galilea as ' $n$ 'terra Christiana' waar die paroesie verwag word, en nie so sterk op die idee van Galilea versus Jerusalem soos Lohmeyer en Lightfoot nie. Dat hierdie teëstelling egter implisiet in sy werk teenwoordig is, sal later aangetoon word. Ons gaan vervolgens daarop in hoe Marxsen by bogenoemde konklusies uitgekom het. 
Marxsen meen dat die Markusevangelie uit 'n reis van Jesus vanaf Galilea na Jerusalem bestaan. Hierdie reis val in twee hoofgedeeltes uiteen, naamlik Jesus in Galilea (Mark 1 tot 9) en Jesus se aktiwiteite in Jerusalem (Mark 11 tot 16). Markus 10 (vgl vers 1) funksioneer in hierdie raamwerk as die oorgang. Bogenoemde reis word deur Marxsen onder drie afdelings bespreek, en hy gaan soos volg te werk:

\subsubsection{Galilea vóór die reisverhaal}

Volgens Marxsen kom die noue relasie wat daar tussen Jesus en Galilea in die Evangelie bestaan, die duidelikste na vore in die eerste paar hoofstukke van die Markusevangelie. Markus 1: 9, 14, 16, 28 en 39 en Markus 3: 7-8, wat almal volgens Marxsen redaksioneel van aard is, is hier van belang.

Markus 1: 9 word soos volg deur Marxsen verklaar: Jesus word hier getipeer as iemand wat kom van 'Nasaret in Galilea'. Volgens Marxsen het die tradisie bloot 'Nasaret' gelees, maar deur die byvoeging van 'in Galilea' koppel die evangelis, deur redaksionele arbeid, die herkoms van Jesus dadelik sterk aan Galilea.

Dieselfde beginsel van redaksionele arbeid kom volgens Marxsen ook in vers 14 en 16 voor. Markus 1: 14 dui aan dat Jesus na Galilea gaan om die evangelie te gaan verkondig. By Markus 1: 16 weer voeg die evangelis 'langs die See van Galilea' in die tradisie in. Die doel van die evangelis se redaksionele arbeid is dus duidelik: Jesus kom nie net van Nasaret in Galilea af nie, gaan nie net na Galilea om sy verkondiging daar te begin nie, maar roep ook sy dissipels 'langs die See van Galilea'. Hierdie is drie duidelike gevalle waar die evangelis deur sy redaksionele arbeid Galilea voorop in die Evangelie plaas.

Ook met Markus 1: 28, meen Marxsen, wil die evangelis dieselfde toespitsing op Galilea beklemtoon. In Markus 1: 21 leer Jesus die mense in die sinagoge wat lei tot die element van verbasing onder die skare (Mark 1: 22). By hierdie lering voeg die evangelis, deur redaksie, die vertelling van die man met die bose gees en 'n parallelle element van verbasing in Markus 1: 27 by. Wanneer hierdie twee verhale in Markus 1: 28 saamgevat word, voeg die evangelis egter weer 'in Galilea' by, en val die klem dus weer eens op Galilea. In Markus 1: 39 word hierdie beklemtoning van Galilea deur die evangelis, volgens Marxsen, verder uitgebou. Die gedeeltes Markus 1: 35-38 (as nabetragting van die dag se gebeure in Kapernaum), sowel as Markus 1: 40-45, beskou Marxsen as tradisiemateriaal. Indien Markus 1: 35-45 sonder vers 39 gelees word, is die verloop van die verhaal duidelik. Die lering in die 
sinagoge, die genesing van die besetene en die genesing van die melaatse vind al drie in Kapernaum plaas, met Markus 1: 38 wat die deur oopmaak vir die verdere prediking van Jesus. Die evangelis stel met vers 39 egter weer 'n grens, naamlik Galilea. Marxsen meen dat die evangelis met die invoeging van vers 39 duidelik die logiese verloop van die vertelling in Markus 1: 35-45 onderbreek, maar omdat Galilea primêr van belang is, dit die evangelis nie werklik hinder nie.

Laastens is Markus 3: 7-9 volgens Marxsen ook die produk van die redaksionele arbeid van Markus. Markus lewer hier getuienis van 'n menigte mense wat van Judea, Jerusalem, Idumea, Tirus en Sidon na Galilea toe kom om Jesus te volg. Al hierdie mense is in Galilea getuies dat Jesus as Seun van God duiwels uitdryf. So tipeer die evangelis Galilea dus as die plek waar die evangelie verkondig word, maar ook geglo word.

Samevattend kan die optrede van Jesus tot dusver in die Markusevangelie dus soos volg beskryf word: Hy kom van Galilea af (Mark 1: 9), begin sy bediening daar (Mark 1: 14), roep sy dissipels daar (Mark 1: 16) en brei sy roem uit deur die hele Galilea (Mark 1: 28). Jesus werk dus nog net in Kapernaum. Wanneer Hy Kapernaum verlaat, gaan Hy na die hele Galilea (Mark 1: 39), maar kom die menigte mense ook na Galilea om sy verkondiging te hoor en te glo. Markus wil dus die indruk skep dat Jesus enersyds nie buite Galilea optree nie, maar andersyds regdeur Galilea werksaam is (Marxsen 1969: 62). Dit wil dus lyk of Marxsen, deur redaksie en tradisie in die Markusevangelie te onderskei, sterk standpunt inneem wat betref die belangrikheid van Galilea vir die evangelis. Die bestaande tradisie in die evangelie lê nie juis veel klem op Galilea nie, maar deur die prominensie van Galilea in die redaksie uit te lig, word die toespitsing op Galilea deur die evangelis duidelik. Dit is dan ook op grond van hierdie gevolgtrekking dat Marxsen (1969: 66) die Markusevangelie as 'n 'Galilean Gospel' tipeer, asook die feit dat 'all decisive preaching always occurs in Galilee' (Marxsen 1969: 62). Dit bly egter opvallend dat die teenstelling GalileaJerusalem, wat so sterk by Lohmeyer en Lightfoot funksioneer, nie deur Marxsen uitgebou word nie.

\subsubsection{Die geografiese data van die reis in die heidense gebied}

Volgens Marxsen kan die vraag nou gevra word of Markus sy oriëntasie ten opsigte van Galilea ook in die res van sy evangelie handhaaf. Bewus daarvan dat die Markusevangelie se einde op Jerusalem konsentreer, asook van die feit dat daar in Markus 1-9 (die Galilese epog) van 
optredes en verkondiging van Jesus buite Galilea berig word, glo hy nie dat hierdie gegewens die teologiese intensie van die evangelie verydel nie.

Indien in ag geneem word dat die middelgedeelte van die Evangelie (hoofstukke 4-9) nie 'n koherente reisplan bevat nie, meen Marxsen dat sy bogenoemde standpunt bly staan. Tog is hierdie gedeelte nie sonder sy probleme nie.

Die argument klop goed tot en met hoofstuk sewe. In Markus 4: 10 lees ons dat Jesus by die see is en in Markus 4: 35 dat Hy na die oorkant van die see vertrek. Die stilmaak van die storm (Mark 4: 35-41) vind logies op die see self plaas, en in Markus 5: 1 bevind Jesus en sy dissipels hulle aan die oorkant van die see. By Markus 5: 21 is Jesus weer terug waarvandaan Hy en sy dissipels in Markus 4: 35 vertrek het, en Markus 6: 1 speel in sy tuisdorp af - alles gegewens wat volgens Marxsen in die tradisie self gefikseer is. In Markus 6: 30-33 bevind Jesus Hom weer by 'n plek wat met 'n boot bereik kan word (en dus naby die see) en in Markus 6: 53 in Gennesaret. Tot en met hoofstuk 7 beweeg Jesus dus nie weg van die See van Galilea en die omgewing daarvan (soos bv Dekapolis) nie. Belangrik om op te let is die feit dat Marxsen hier swaar steun op die siening dat Galilea in die tyd van Jesus nie gesien is as net die gebied wes van die see nie, maar ook as die gebied rondom die see. ' $n$ Siening wat impliseer dat Dekapolis dus ook in die gebied van Galilea geval het.

In Markus 7: 24 neem Jesus se reis in die heidense gebied egter 'n aanvang. Jesus betree nou die gebied van Tirus (en Sidon). Tog meen Marxsen dat hierdie gebiede ook met Galilea in verband gebring kan word. Die rede hiervoor is dat Tirus en Sidon albei stede is wat deel uitgemaak het van Dekapolis. Dekapolis is egter reeds hierbo deur Marxsen aan Galilea gekoppel deur sy verduideliking van die omvang van die gebied waaruit Galilea in die tyd van Jesus sou bestaan. Dus vind hierdie optredes van Jesus nog steeds in en om Galilea plaas, aldus Marxsen.

Die laaste probleem duik op by Markus 8: 27. Wanneer hierdie verwysing na Sesarea-Filippi egter in verband met Markus 9: 30 gebring word, lewer dit syns insiens geen probleem op nie. Volgens Marxsen is hier 'n baie breë parallel in die teks tussen Markus 7: 24 en Markus 7: 31 aan die een kant, en Markus 8: 27 en Markus 9: 30 aan die ander kant teenwoordig. Soos Jesus se optrede in Tirus in Markus 7: 24 teruglei na Galilea in Markus 7: 31, so lei Jesus se optrede in Markus 8: 27 (in Sesarea-Filippi) in Markus 9: 30 ook weer terug na Galilea. In 
hierdie gedeeltes is daar dus ' $n$ reisplan ter sprake wat wel na die heidense gebied beweeg, maar telkens teruglei na Galilea. Dus staan Galilea steeds in die sentrum van die evangelis se intensie. Ook wat die eerste lydingsaankondiging betref, is laasgenoemde waar. Die eerste lydingsaankondiging (Mark 9: 31) kom sonder enige spesifieke lokaliteitsaanduiding in die tradisie voor. Die evangelis voeg egter volgens Marxsen in Markus 8: 31 Galilea by, wat weer eens ' $n$ aanduiding is van sy 'teologiese' gerigtheid op Galilea in die Evangelie.

Indien ons bogenoemde eksegese van Marxsen aanvaar, wil dit dus lyk of die hipotese van Marxsen bly staan. Tot en met Markus 7: 24 kan alle optredes van Jesus gereduseer word tot die See van Galilea (en Dekapolis). Na Markus 7: 24 gebruik Markus die tradisie soos dit voorkom, maar laat deur redaksionele arbeid (Mark 7: 31 en Mark 9: 30) die reis in heidense gebied telkens teruglei na Galilea. So bly Galilea die fokus van die Markusevangelie tot en met hoofstuk 9.

\subsubsection{Galilea in Markus 11-16}

Soos reeds aangetoon, beskou Marxsen Markus 10 as die oorgang tussen die Galilese epog (hfst 1-9) en die reis na Jerusalem (hfst 11-16) in die Markusevangelie. Wanneer Marxsen hom rig tot die hantering van laasgenoemde reis, werk hy hoofsaaklik net met Markus 14: 28 en Markus 16: 7.

Volgens Marxsen is daar ' $n$ baie noue verwantskap tussen hierdie twee verse. Formeel is die verband dat Markus 14: 28 in die futurum staan, terwyl Markus 16: 7 in die praesens voorkom. Die verband hier is dus een van belofte en vervulling. Tweedens moet albei verse ook as redaksioneel gesien word.

Wat Markus 14: 28 betref, meen Marxsen dat hierdie vers duidelik tussen vers 27 en 29 ingevoeg is. Behalwe dat dit die eenheid van die verloop van die verhaal verbreek, is dit veral die voorkoms van skandalisthēsontai in vers 29 en skandalisthèsesthe in vers 27 wat aantoon dat vers 29 in die tradisie op vers 27 gevolg het. Wat vir Marxsen egter hier van belang is, is die feit dat hierdie vers in die bogenoemde belofte-vervulling skema voorbereiding tref vir Markus 16: 7.

Die perikoop waarin Markus 16: 7 voorkom, naamlik Markus 16: 1-8, is volgens Marxsen ook nie sonder probleme nie. Dit is veral die teëstelling tussen vers 7 en 8 wat volgens Marxsen dadelik die aandag trek, omdat die stilswye van die vroue in vers 8 duidelik in kontras staan met die opdrag van die engel in vers 7 . Hoe moet hierdie teëstelling verstaan word? 
Marxsen meen dat Markus 16: 7 redaksioneel van aard is en daarom deur die evangelis om ' $n$ bepaalde rede tussen vers 6 en 8 ingevoeg is. Die vraag wat daarom volgens Marxsen beantwoord moet word, is die volgende: Hoe het Markus hierdie vers verstaan en wat wou hy daarmee bereik deur dit tussen vers 6 en 8 in te voeg? Marxsen meen dat hy tot dusver duidelik aangetoon het dat Galilea enersyds vir die evangelis besondere betekenis gehad het en andersyds as lokaliteit baie nou gekoppel was aan die eietydse gemeente van die evangelis. Met dít in gedagte, is dit daarom duidelik dat Markus 16: 7 nie histories of in isolasie van die agtergrondgegewens van die evangelis se gemeente verklaar kan word nie. Om hierdie rede moet die verklaring van hierdie vers gekoppel word aan die betekenis wat Galilea vir die evangelis gehad het en wat Markus met sy redaksie beoog het. Soos reeds aangetoon, meen Marxsen, het dit duidelik geword dat Markus deur redaksionele aktiwiteit telkens Galilea in die fokus van die Evangelie geplaas het, en dat dit veral die See van Galilea is wat as 'n soort vergaderplek vir die gemeenskap in die tyd van die evangelis gedien het. Ook is reeds aangedui dat Markus met Markus 14: 28 voorbereiding vir Markus 16: 7 getref het. Om hierdie redes het die evangelis dus Markus 16: 7 ingevoeg. Ons het met ander woorde in Markus 16: 7 te doen met wat genoem kan word die laaste stratum van die Sitz-im-Leben Ecclesiae van die gemeente van Markus. Vir Marxsen kom dit dus op die volgende neer: 'This redaction (therefore - EvE) cannot deal with an appearance of the Risen Lord awaited in Galilee; in Mark's context this passage can only refer to the expected parousia' (Marxsen 1969: 88). Die redaksionele arbeid moet dus gekoppel word aan die werderkoms van Jesus en nie aan die verskyning van die opgestane Christus soos Lohmeyer beweer nie.

Marxsen meen dat, indien bogenoemde verklaring van Markus 16: 7 aanvaar sou word, 'n hele aantal probleme so opgelos word. Eerstens word die teëstelling tussen vers 6 en 8 baie maklik hieruit verklaar. As Markus 16: 7 ingevoeg is as voorbereiding vir die paroesie, is die verband tussen vers 6 en 8 wel sinvol en word die teëstelling tussen hierdie verse opgehef. Tweedens word dit hieruit ook duidelik hoekom die Evangelie juis by Markus 16: 8 ophou. Die frase 'daar sal julle Hom sien', is vir Markus futuristies van aard.

Die paroesie moet nog plaasvind. Terselfdertyd moet die evangelis se gerigtheid op Galilea, as die plek waar Markus en sy gemeente die paroesie verwag, in die oog gehou word: Dit is die fokuspunt van sy Evangelie en daarom vergader die gemeente by die See van Galilea. 
Laastens verklaar bogenoemde verklaring van Markus 16: 7 ook die werkwoord proágein in Markus 16: 7 en Markus 14: 28. Jesus het sy dissipels vooruitgegaan na Galilea. Hy is reeds daar, wel nog verborge, maar sal met die paroesie gemanifesteer word. Soos Markus 1: 1 Jesus se optrede karakteriseer as verkondiging, so ook die geval in Markus 16: 7 en 8.

\subsection{Samevatting}

Markus skryf duidelik 'n Galilean Gospel (Marxsen 1969: 66). 'n Gevolgtrekking wat duidelik word uit die feit dat Markus telkens in sy redaksionele arbeid Galilea voorop plaas. So kry Galilea nie net 'geografiese betekenis' nie, maar teologiese betekenis as die plek van die verwagte paroesie van Jesus. Hoe hierdie gedagte by Markus tot stand gekom het, val volgens hom in drie stadia van tradisie-ontwikkeling uiteen:

- Die eerste is dié van die historiese Jesus. Hy tree op, na die beste van ons wete, in Galilea.

- Die tweede stadium is dié van die primitiewe gemeenskap wat waarskynlik aan Jerusalem gekoppel kan word. Die Paulusbriewe is die belangrikste getuienis hiervan. Hierdie gemeente het egter nie tot Jerusalem beperk gebly nie, maar het later na Galilea begin verskuif. Soos die verskuiwing plaasgevind het, het die verwagting dat die paroesie in Galilea sou plaasvind, ontstaan. Maar waarom juis Galilea? Waar die eerste koms van Jesus plaasgevind het, daar ook die tweede.

- Die derde stadium is dié van Markus self. Die gerigtheid op Galilea is ten tye van sy skrywe van die evangelie reeds 'n feit. Markus span daarom die individuele tradisies só in dat bogenoemde gerigtheid op Galilea duidelik in sy evangelie na vore tree. So proklameer hy, met Galilea as die besonderse karakter van hierdie proklamasie.

\section{GALILEA EN JERUSALEM: 'N NARRATOLOGIESE EVALUERING VAN MARXSEN SE BYDRAE}

Die insig dat die evangelies vertellinge is, het die deur geopen om die Galilea-Jerusalem verhouding in die Markusevangelie ook vanuit 'n ander interpretasiemodel te bestudeer as die redaktionsgeschichtliche benadering. Die vraag ontstaan egter nou, in die lig van Marxsen se bydrae, of die aspek belangeruimte in sodanige benadering nuwe 
perspektiewe met betrekking tot hierdie probleem open al dan nie (vir 'n verduideliking van die betekenis en funksie van hierdie term kyk Van Eck 1986: 339-349). Dit blyk wel die geval te wees. Wanneer daar erns gemaak word met die plot en die ideologiese perspektief van die verteller van die Markusevangelie, word bogenoemde verhouding vanuit ' $n$ ander hoek bekyk. Vervolgens word daar dan ingegaan op enkele ondersoeke wat in hierdie verband vanuit 'n narratologiese benadering gedoen is. Slegs die essensiële van hierdie studies word weergegee ter wille van die bondigheid en lengte van die onderhawige artikel. Vir 'n vollediger bespreking kyk Van Eck 1984: 28-51.

\subsection{David Rhoads en Donald Michie}

Volgens Rhoads en Michie bestaan die Markusevangelie uit ' $n$ reis van Jesus vanaf Galilea na Jerusalem. Die eerste helfte van die Evangelie (Mark 1: 1 tot Mark 8: 26) speel af in Galilea, en vanaf Markus 8: 27 tot Markus 10: 52 beweeg Jesus deur die heidense gebied na Jerusalem waar die res van die evangelie (Mark 11: 1 tot 16: 8) dan afspeel.

Belangrik egter is die feit dat die motief van die weg (as belangeruimte) die tematiese struktuur van hierdie reis bepaal. In Jesus se omwandelinge in Galilea word daar reeds in Markus 1: 2 twee maal na die weg verwys, en kom hierdie motief van die weg verder nog vier keer tot Markus 8: 26 voor, te wete Markus 4: 4; 4: 15; 6: 8 en 8: 3 . In Jesus se reis na Jerusalem (Mark 8: 27 tot Mark 16: 8) kom die motief van die weg verder ook nie minder as agt keer voor die (Mark 8: 27; 9: 33, 34; 10: 17, 32, 46, 52; 11: 8; 12: 14). Vir Rhoads en Michie is dit dus duidelik dat die fraseologies gebruik van die motief van die weg struktuur of betekenis aan die Evangelie gee. Hulle formuleer hierdie gevolgtrekking soos volg: 'The settings (veral die weg - EvE) provide the overall framework for the movement and the development of the plot' (Rhoads \& Michie 1982: 63).

Hierdie weg van Jesus is die weg van God. Om op die weg te wees, beteken daarom veel meer as ' $n$ fisiese beweging vanaf Galilea na Jerusalem. Dit is die weg wat Jesus moet volbring soos deur God beplan, ' $n$ lydensweg tot die dood in gehoorsaamheid in diens aan die kerugma. Vir die dissipels, aan die ander kant, impliseer dit ' $n$ reis weg van onbegrip na die verstaan van wat die weg van Jesus werklik beteken. So eindig die vertelling dan ook ironies in Jerusalem waar almal rondom Jesus sy teenstanders geword het, selfs die dissipels. Ook word hierdie motief van die weg uitgebeeld deur Jesus se oproep tot 
navolging, uitgedruk deur die frases 'om My vooruit te gaan' en ook 'om My te volg' (Rhoads \& Michie 1982: 65).

In hierdie struktuur, wat grootliks deur die belangeruimte van die weg gedra word, is die funksie van Galilea en Jerusalem dan, volgens Rhoads en Michie, dié van belangeruimtes ondersteunend tot die Leitmotiv van die Evangelie, naamlik die weg. In Galilea verwissel Jesus nie minder as veertig keer van plek nie, 'n 'gejaagdheid' wat dui op die dringendheid van Jesus se boodskap, 'n Boodskap van wat die weg van God beteken, en wat ook deur baie geglo word. In Jerusalem word hierdie weg van God tot 'n einde gedryf deur die reiniging van die tempel, die bevraagtekening van die outoriteit van Jesus deur die skrifgeleerdes en sy dood. Die finale afloop van die vertelling wys egter weer terug na Galilea, met die bevel aan die dissipels om terug te keer na die See van Galilea om weer van voor af te begin. ' $n$ Nuwe begin vir die dissipels en almal wat kies om hierdie weg van God te bewandel. ' $n$ Begin wat egter ook impliseer dat almal wat kies om Jesus te volg, ook op hulle weg bereid sal moet wees om die teëstand wat Jesus ervaar het, te ervaar.

Rhoads en Michie se interpretasie van die Evangelie is dus duidelik: Sentraal in die Evangelie staan die Leitmotiv van die weg van God, met Galilea en Jerusalem dan (as verdere belangeruimtes) as begronding van hierdie weg van God.

\subsection{Bas van Iersel}

Volgens Van lersel (1982a: 117) het alle studies wat oor die GalileaJerusalem verhouding in die Markusevangelie gedoen is, een leemte in gemeen. ' $n$ Leemte wat daaruit bestaan dat daar wel erns gemaak is met die Galilea-Jerusalem verhouding, maar sonder inagneming van die verhouding van Galilea en Jerusalem tot ander belangeruimtes in die Evangelie. Van Iersel (1982a: 119) formuleer sy vertrekpunt daarom soos volg: 'Mijn bijdrage beoogte de voornaamste plaats aanduidingen in Marcus te analyseren als een samehangend topografisch systeem, dat een functie heeft voor de betekenis van het boek.' Dus nie net 'n blote bestudering van die topografie van die Markusevangelie nie, maar meer ' $n$ interesse in die topografiese geweefdheid van die teks.

Wanneer hierdie geweefdheid van belangeruimtes in die teks in ag geneem word, meen Van Iersel dat die struktuur van die Evangelie diagrammaties soos volg voorgestel kan word (vir'n volledige struktuur vgl Van Eck 1984: 34-36): 
die woestyn

Galilea

die weg

Jerusalem

die graf
Markus 1: 1-1: 13

Markus 1: 14-8: 26

Markus 8: 27-10: 52

Markus 11: 1-15: 45

Markus 15: 46-16: 8

'n Struktuur wat, volgens Van lersel, bepaal word deur 'n relasie van ooreenstemming ( $\mathrm{nl}$ die woestyn en die graf) en 'n relasie van opposisie (nl Galilea en Jerusalem). Die belangeruimte van die weg staan duidelik sentraal.

Wanneer hierdie vyf sekwensies van naderby bekyk word, is Van Iersel (1983: 48) van mening dat dit op tweërlei wyse in die Evangelie funksioneer. Eerstens is daar die streng liniêre verloop (oppervlaktestruktuur op die sintagmatiese vlak) van die sekwensies soos in die diagram aangedui, en tweedens die sisteem van relasies wat primêr gerig is op die leser van die Evangelie ( $\mathrm{d}$ w s die dieptestruktuur op die paradigmatiese vlak van die vertelling). Laasgenoemde is die konsentriese rangskikking van enersyds Galilea en Jerusalem (as opposisie), en andersyds die woestyn en die graf (as ooreenkoms) rondom die middelste sekwensie van die weg.

Volgens Van Iersel word die opposisie Galilea-Jerusalem veral uitgedruk deur die volgende teëstellinge: platteland teenoor stad; oorvloedige vrugte teenoor geen vrugte; Jesus doen goed aan ander teenoor ander wat kwaad aan Jesus doen en genesings teenoor geen genesings (vir 'n volledige diagram vgl Van Iersel 1982: 126). Die ooreenkoms tussen die woestyn en die graf word op sy beurt weer uitgedruk deur onderskeidelik die eskatologiese boodskappers in Markus 1: 7-10 en Markus 16: 6, uitsprake van Jesus oor die weg in Markus 1: 1-2 en Markus 16: 7, en die verwysings na die dood (as suggestie) en die lewe in beide die sekwensies oor die woestyn en die graf.

Die struktuur van die Markusevangelie is daarom vir Van lersel duidelik: Sentraal staan die weg waarop Jesus moet gaan. Die sekwensies van die woestyn en die graf beskryf hierdie weg as 'n weg waar daar gesterf moet word, maar waar lewe ook weer ' $n$ werklikheid sal word. Daar sal egter op hierdie weg konflik wees, soos deur die teëstelling tussen Galilea en Jerusalem gesuggereer word. Jesus se weg is dus ' $n$ weg van lyding. Van lersel (1984: 50) som hierdie weg dan ook ten slotte soos volg op: 'It is impossible to go on the way of Jesus if one does not know its course, or rather does not see Jesus going on before 
... one can only follow Jesus if he understands Him ... if he actually wants to follow Jesus on the way to the end.'

\subsection{Elizabeth Malbon}

Volgens Malbon is die grootste leemte in die werk van Marxsen die feit dat hy teologie in eskatologie laat opgaan. Hierdie leemte in die werk van Marxsen is die gevolg van twee onaanvaarbare vooronderstellinge waarvan Marxsen uitgaan: Eerstens is dit die feit dat Marxsen sy bestudering van die Markusevangelie baseer op 'n historiese vertrekpunt dat Galilea die plek is waar die eskatologiese gebeure in Christus verwag is. Tweedens meen Malbon dat Marxsen teologie tot topografie en topografie tot teologie verhef het in sy bestudering van die Evangelie.

Dit is vir haar daarom duidelik dat die topografie van die Evangelie nie in die konteks van die historiese wêreld van die teks gesien moet word nie, maar dat die topografie van die Markusevangelie eerder bestudeer moet word in die konteks van die teks as literêre wêreld. Vir haar is dit dus baie belangrik dat 'the investigation of the relation of the text to its historical world may not proceed in ignorance or disdain of the text itself or of the relation of the text to its literary world (Malbon 1982: 247).

Wanneer die teks op laasgenoemde wyse bestudeer word, meen Malbon, is een van twee wyses van bestudering moontlik, te wete diakronies of sinkronies:

- 'n Diakroniese studie lê klem op die kronologiese verloop van die gebeure in die teks soos dit afspeel vanaf Markus 1: 1 tot Markus 16: 8. Soos die leser liniêr deur die teks lees, kom, volgens Malbon, duidelike patrone van voorafskaduwing na vore. Die aanvanklike reis van Jesus na Judea (Mark 1: 9) gryp byvoorbeeld só vooruit na Jesus se latere reis na Jerusalem, en Jesus se terugkeer vanaf die woestyn (Mark 1: 14) dien as vooruitskoue vir Jesus se finale terugkeer na Galilea uit die graf. Jesus se Galilese bediening is daarom ook duidelik prospekties ten opsigte van die na-Pase optrede van die volgelinge van Jesus.

- Die sinkroniese bestudering van die Evangelie behels op sy beurt weer 'n ondersoek van die breë sisteem van relasies van opposisie en mediasie in die Evangelie. Die mees dramatiese kontras in die Markusevangelie is dié tussen land $(g \bar{e})$ en see (thálassa), 'n teëstel- 
ling wat onderliggend is aan die hele Evangelie. Hierdie teëstelling impliseer op sy beurt weer die teëstelling tussen orde en chaos wat weer vervang kan word met die relasie tussen Jesus se tuiste en vreemde land (tuiste); 'n opposisie wat laastens, volgens Malbon, met die teëstelling Galilea en Jerusalem vervang kan word. In laasgenoemde teëstelling vind daar egter 'n omkering plaas. Tradisioneel staan Jerusalem (met die tempel waar God teenwoordig is) vir orde in die Evangelie, en Galilea, omring deur vreemde lande tesame met die chaotiese [sic] prediking van Jesus, vir die chaos. Die omkering vind egter plaas as Jesus met sy optrede en verkondiging van die 'regte' evangelie orde skep in Galilea en chaos in Jerusalem as Hy daar die nuwe orde aankondig en gekruisig word. Albei belangeruimtes word dus so ten goede verander wanneer dit in verhouding tot Jesus se 'nuwe' boodskap gesien word.

- Vir Malbon (1982: 253) is dit dus duidelik dat, wanneer bogenoemde sisteem van relasies op die sinkroniese leesvlak van die vertelling verstaan word, ook die teologiese betekenis van die Markusevangelie gesnap kan word. Deurdat die teëstellings in die Evangelie uitmond in die relasie tussen Galilea en Jerusalem, ' $n$ relasie wat sy begronding vind in die 'nuwe' evangelie wat Jesus verkondig, word ingesien dat die Markusevangelie beoog om 'the beginning of the good news of Jesus Christ, the Son of God ( $d$ w s die weg van God EvE) te wees (Malbon 1982: 255).

\subsection{Willem Vorster}

Volgens Vorster (1980: 110) '. . . kan dit sonder twyfel beweer word dat Markus se evangelie tot vertelliteratuur behoort en dat dit beskou moet word as 'n dramatiese vertelling'. Juis daarom sal 'n uitgangspunt met die teks as vertelling beter resultate lewer as die redaktionsgeschichtliche benadering van Marxsen.

Vorster verskil van Marxsen veral wat betref Markus 14: 28 en Markus 16: 7. Soos reeds gesien, dui hierdie twee verse volgens Marxsen op die spoedige wederkoms van Christus in Galilea. Vorster bou sy argument op twee sake: Eerstens is dit ' $n$ vraag of Markus wel 'n spoedige wederkoms geprogapeer het. Hier lê Vorster veral klem op Markus 13 wat volgens hom eerder op 'n vertraging van die wederkoms dui. In die tyd van Markus se skrywe is daar dus reeds met die vertraging van die paroesie rekening gehou.

Tweedens lees Marxsen volgens Vorster te veel in die woord 'sien' in 
(Mark 16: 7). Dit is onseker of die woord 'sien' hier na 'n spoedige wederkoms verwys. Ook is dit opvallend dat Jesus in sy drie lydingsaankondigings (Mark 8: 31; 9: 31; 10: 33) geen melding van sy wederkoms maak nie. Die teëstelling tussen Galilea en Jerusalem vervul volgens Vorster egter wel 'n belangrike funksie in die Markusevangelie. Hy formuleer dit soos volg: 'Galilea word oorbeklemtoon om dit in kontras te stel met Jerusalem, die setel van die Joodse godsdiens en die plek waar Jesus gesterf het' (Vorster 1980: 137).

\subsection{Norman Petersen}

Soos by Vorster is Petersen ook van mening dat wanneer daar oor die wederkomsgedagte in die Markusevangelie gepraat word, Markus 13 nie tersyde gestel kan word nie. Petersen plaas Markus 16: 7 dan ook in die perspektief van Markus 13.

Van Marxsen se benadering sê hy die volgende:

... to read it (die Markusevangelie - EvE) as redaction is to focus on a redactor and its sources and that has its critical place, but to do so is to block the possibility of entering into the narrative world to which the narrator invites our imaginative selves and offers his service as our guide. The rhetoric point of view (die ideologiese perspektief - EvE), once we know how to look for it, is the best tangible device we have to help us teach ourselves to listen what the narrator is telling us (Petersen 1978: 118).

Vanuit bogenoemde invalshoek wil Petersen dus die relasie van Markus 13 en Markus 16: 7 bepaal. In die Evangelie self reken hy dat daar 'n konstante verhouding tussen voorspelling en vervulling teenwoordig is en dat dit so aangebied word dat die voorspellings in die Evangelie altyd in vervulling gaan. Om hierdie rede is dit nodig dat Markus 16: 7-8 gelees sal word in terme van die hele Evangelie, maar veral in relasie met die verwagtinge wat deur die verteller in die vertelling geskep word. In dié lig, meen Petersen, kan die einde van die Markusevangelie as 'n 'open end' beskou word. Alhoewel die teks eindig, eindig die literêre funksie van die implisiete leser nie. Ons moet dus aanvaar of dat die voorspelling in Markus 16: 7 sy vervulling in die Evangelie het of dat Markus, wat hierdie voorspelling betref, inkonsekwent is. Eersgenoemde is volgens Petersen die geval, sodat Markus 16: 7 sy vervulling in die Evangelie het, en wel in Markus 13. 
Petersen bou hierdie stelling op die onderskeid wat daar in 'n vertelling bestaan tussen die narratiewe wêreld en die narratiewe teks van die verteller. Waar eersgenoemde gebeure bevat wat voor en ook na die vertelling plaasvind wat hy aanbied, daar dui laasgenoemde op 'n verkorting (of seleksie) uit die totale narratiewe wêreld van die verteller. ' $n$ Gebeurtenis wat na die vertelde teks van die verteller plaasvind, kan egter ook in die vertelling self ( $\mathrm{d}$ w s die narratiewe teks) opgeneem word. Volgens Petersen dui Markus 13 op so 'n gebeure. Met hierdie literêre beginsel in gedagte, asook die konstante verhouding van voorspelling en vervulling in die Evangelie, meen Petersen (1980: 159) dat Markus 16: 8 op een van twee wyses geïnterpreteer kan word: òf literêr ò ironies.

'n Literêre lees van die Markus 16: 8 lewer die volgende op: Die vertelling kom tot 'n skerp, abrupte einde met 'n negatiewe dissipelbeeld. Volgens Petersen (1978: 93-121) word 'n negatiewe dissipelbeeld wel regdeur die Evangelie geteken. Hulle verstaan van wie en wat Jesus is, bly totaal anders as wat Jesus wil hê dit moet wees. Die einde van die vertelling (Mark 16: 8) moet hierdie dissipelbeeld dus òf bevestig ò iets impliseer wat 'n oplossing vir die probleem bied. Markus 16: 8 laat hierdie vraag egter onbeantwoord; dus verbreek die verteller sy konsekwente verhouding tussen voorspelling en vervulling in die Evangelie. Petersen (1980: 162) formuleer die gevolg van hierdie hantering van Markus 16: 8 dan ook soos volg: 'A reading of Mark's narrative predicted on a literal interpretation of its closure in 16: 8 is (therefore-EvE) not literarily impossible, but its results assault its own credibility.'

Die oplossing van die probleem van die interpretasie van Markus 16: 8 lê vir Petersen daarom in 'n ironiese lees van Markus 16: 8. Dit vestig die leser se aandag op die direk voorafgaande, naamlik dat Jesus wel opgestaan het, en dat hy die dissipels wel vooruitgegaan het na Galilea. Al het die dissipels Jesus wel in Markus 14-15 verlaat, het sy voorspelling tog waar geword. Hy het opgestaan en na Galilea gegaan, soos voorspel is.

Indien ons nou Markus 16: 8 as die brug sien tussen die 'plotted time' (narratiewe teks) en die 'implotted time' (narratiewe wêreld) in die Evangelie, word Markus 16: 8 en Markus 13 so nie net kronologies (d w s opeenvolgend) aan mekaar verbind nie, maar word Markus 13 ook die sleutel tot die verstaan van Markus 16: 8. Wat bedoel Petersen hiermee?

Volgens Petersen is dit in Markus 13 duidelik dat die dissipels hier 
verstaan wie Jesus werklik is. Hulle verdedig Hom selfs teen die valse leraars - 'n duidelike verandering in die insig van die dissipels oor wie en wat Jesus regtig is wat slegs teweeggebring kon word indien die ontmoeting waarvan in Markus 16: 7 berig word, wel plaasgevind het. Dus moet Markus 13, in terme van die voorspelling-vervulling skema in die Evangelie, volgens Petersen gesien word as die werklike einde van die Evangelie. Die verband tussen discourse time en story time in die Evangelie word só ook finaal vasgelê. Deur hierdie inbedding van Markus 13 in die Evangelie word dit dus ook duidelik dat Markus 16: 7-8 nie, soos Marxsen beweer, op 'n spoedige wederkoms in Galilea dui nie, maar op 'n ontmoeting met die opgestane Heer. Ook word die konsekwente verhouding tussen voorspelling en vervulling in die Evangelie so gehandhaaf.

\section{EVALUERING}

Uit die resultate van die evaluering van Marxsen se standpunt in afdeling 4 het dit duidelik geword dat ' $n$ narratologiese benadering tot die Markusevangelie ons gebring het tot 'n dieper insig van veral die funksie van die belangeruimtes Galilea en Jerusalem en die probleem rondom die wederkomsgedagte in die Markusevangelie. Hiermee word egter nie bedoel dat ' $n$ narratologiese lees van die Markusevangelie al die gevolgtrekkings waartoe Marxsen geraak het met sy redaktionsgeschichtliche lees van die Evangelie, opgehef word nie. Daar sal daarom nou oorgegaan word om die raakpunte tussen die gevolgtrekkings van Marxsen (kyk weer afdeling 3 ) en dié van 'n narratologiese lees van die Markusevangelie aan te toon.

Die vertellersperspektief-analise (kyk Van Aarde 1983a: 58-83) het aangetoon dat ' $n$ vertelling (soos die Markusevangelie) uit meer as een handelingslyn kan bestaan (vgl Lammert in Van Aarde 1984: 3). Hierdie insig in die vertelkunde het verder aangetoon dat die ideologiese perspektief van die verteller (wat die hele vertelling dra en stuur), veral te vinde is in die verhouding waarin hierdie handelingslyne (twee of meer) tot mekaar in die vertelling staan. In die Markusevangelie is dit dan inderdaad ook die geval. Twee handelingslyne kan in die Evangelie aangetoon word, naamlik die handelingslyn van die Jesussending en die handelingslyn van die dissipelsending.

Tannehill (1980: $60 \& 62$ resp) beskryf hierdie twee handelingslyne soos volg: 
The Gospel of Mark is the story of the commission which Jesus received from God and of what Jesus has done (and will do) to fulfill this commission ( $\mathrm{d} w \mathrm{~s}$ die Jesussending - EvE).... Although Jesus' commission is central in Mark, many other commissions and tasks are suggested .... In 1: 16-20 Jesus calls four fishermen to follow him. This establishes the disciples' commission and begins a sequence of events ( $d$ w $s$ die dissipelsending - EvE).

Daar kan dus duidelik twee handelingslyne in die Markusevangelie aangetoon word: die sekwensiële vlak van die Jesussending en die sekwensiële vlak van die dissipelsending (Van Aarde 1982: 128).

Volgens Van Aarde (1982: 131) bestaan daar verder altyd 'n parallelle verband, oftewel analogie, tussen die 'gebeure' van die eerste handelingslyn en dié van die tweede. Dit kom dus daarop neer dat die eerste-vlak vertelling die tweede-vlak vertelling in die oog het, met die ideologiese perspektief van die verteller geleë in die analogie tussen hierdie twee handelingslyne.

Vorster (1980: 129) druk hierdie analogie inhoudelik soos volg uit: Die doel van die protagonis (Jesus) is om die Koninkryk van God daar te stel. Hy behaal sukses deur mense te leer en gesond te maak, maar sterwe later. Hy oorwin egter deur sy opstanding. Dit kan ook beskryf word as Jesus se weg van lyding in gehoorsaamheid aan die Vader. Die tweede sekwensie wat hiermee parallel loop, is dié van die dissipelsending. Jesus roep die dissipels (Mark 1: 16-20; 3: 1-4), maar nieteenstaande al Jesus se pogings openbaar die dissipels 'n onvermoë om te verstaan wie Jesus regtig is. In Markus 14: 50 verlaat hulle Hom dan ook heeltemal.

Soos Vorster meen Kingsbury (1981: 50-53) ook dat die analogie tussen die twee vertellyne in die Markusevangelie in terme van navolging in lyding gesien moet word. Hy formuleer dit so: 'The root problem is a persistent lack of comprehension on their (die dissipels se - EvE) part .... Indeed, they resist the cardinal truth Jesus would impress on them, namely that the way of Jesus is the way of suffering' (Kingsbury 1981: 152).

Of soos Petersen dit stel: Ongeag die verstaan van wie of wat Jesus is deur die ander karakters in die vertelling, bly die dissipels se verstaan van Jesus totaal anders as wat Jesus wil hê dit moet wees (kyk weer afdeling 4.5).

Insgelyks kan uit die werk van Rhoads en Michie, sowel as uit dié van 
Van Iersel, aangetoon word dat die verklaring van die verhouding tussen die twee vertellyne in die Markusevangelie van groot belang is vir die verstaan van die Evangelie. Volgens eersgenoemde is die hoofmotief van die Evangelie die weg van God, 'n weg wat ' $n$ weg van lyding is. Waar die weg van Jesus deur Johannes die Doper voorberei word, daar dien die weg van Jesus weer as voorbereiding (analogie) vir die weg waarop die dissipels moet gaan. Johannes die Doper word voor Jesus uit gestuur, en Jesus het sy dissipels vooruitgegaan. Die feit dat die weg van Jesus in Jerusalem eindig waar Hy gekruisig word, beteken dus by implikasie dat almal wat Jesus wil volg (ook sy dissipels) bereid moet wees om hierdie selfde lyding en teëstand te ervaar. Ook Van lersel toon aan dat die weg as die fokus van die Evangelie gesien moet word (kyk weer afdeling 4.2).

Die analogie tussen die twee handelingslyne in die Markusevangelie kan op grond van die voorafgaande myns insiens dus soos volg uitgedruk word: Jesus beweeg op die weg van God, 'n weg van lyding. Die dissipels (en alle gelowiges) moet Hom volg, maar ook hulle weg sal 'n weg van lyding wees. Só gesien, kan die ideologiese perspektief van die verteller in die Markusevangelie uitgedruk word as navolging in lyding.

Wanneer laasgenoemde gevolgtrekkings van die narratologiese bestudering van die Markusevangelie met die gevolgtrekkings van Marxsen vergelyk word, kom die volgende na vore: Soos reeds aangedui, het Marxsen enersyds Markus 16: 7 gesien as verwysend na die paroesie en andersyds die klem in die Markusevangelie sterk op Galilea laat val. Marxsen het beweer dat Markus 16: 7 'n produk van die redaksie van die evangelis is en daarom in die konteks van die perikoop waarin dit staan, verklaar moet word. Van Iersel ondersteun Marxsen in hierdie verband wanneer hy die relasie tussen Markus 1: 7 en Markus 16: 7 aantoon. Dit moet daarom aanvaar word dat hierdie vers wel in konteks verklaar moet word. Volgens Marxsen dui hierdie vers dan ook op die paroesie-verwagting in Galilea en weerspieël die vers dus iets van die Sitz-im-Leben Ecclesiae van die gemeente. Hiermee toon Marxsen myns insiens aan dat die na-Pase gebeure (dus ook die tweede handelingslyn) implisiet in die Markusevangelie aanwesig is. Marxsen (1969: 112) toon verder ook aan dat die paroesie en opstanding twee gebeure is, maar dat 'the resurrection has occurred; the Parousia is viewed as imminent. Between the two lies "time", even decades. But the history of the church lies outside the evangelist's horison'. Ons sal dus moet toegee dat Marxsen ingesien het dat die na-Pase gemeente implisiet in 
die Markusevangelie funksioneer, maar nie eksplisiet deur hom uitgebou is nie.

Uit 'n narratologiese bestudering van die Evangelie het dit egter duidelik geword dat Markus die teenwoordigheid van die na-Pase gemeente in die Evangelie wel deeglik benut, veral as daar gekyk word na die funksie van Markus 13 in die Evangelie. Vorster, maar veral Petersen (kyk weer afdelings 4.4 en 4.5 resp), het dit duidelik aangetoon. Waar die twee handelingslyne in die Evangelie self parallel loop en die eerste die tweede in die oog het (in terme van dieselfde soort navolging), maar nooit realiseer nie, daar gebeur dit egter wel in Markus 13 as ' $n$ kontinuering van die handelingslyn op die eerste sekwensie, naamlik dié van die Jesussending. Al eindig die Markusevangelie dus by Markus 16: 8, word dit in der waarheid voortgesit in Markus 13, en wel as ' $n$ kontinuering van die dissipelsending as tweede handelingslyn in die voor-Pase gebeure in die Evangelie.

Op grond hiervan kan Marxsen se siening rakende die wagtende gemeente (na-Pase gemeente) in Galilea in terme van tyd en ruimte aangevul word. Markus 16: 7 dui dus nie op die verwagting van 'n spoedige wederkoms nie, maar daar sal eerder, as gevolg van die teenwoordigheid van die na-Pase gemeente in Markus 13, voorsiening gemaak moet word vir 'n moontlike vertraging van die wederkoms in die Markusevangelie.

Ook die aard van die na-Pase gemeente kan uit die twee handelingslyne wat in die Markusevangelie teenwoordig is, afgelei word. Wanneer daar in ag geneem word dat die teenwoordigheid van die na-Pase gemeente in die Markusevangelie die voortsetting van die tweede handelingslyn verteenwoordig, kom dit daarop neer dat die weg van die na-Pase gemeente in analogie staan met die weg van die voor-Pase Jesus. Waar die weg van die voor-Pase Jesus 'n weg van lyding was, daar is die weg van die na-Pase gemeente dus ook ' $n$ weg van lyding in gehoorsaamheid aan die wil van God. Kingsbury (1981: 57) formuleer dit soos volg: 'The community of Mark looks upon itself as continuing in time with the original disciples of Jesus ... the Marcan community are being summoned by the crucified one to take up one's own cross and to follow after.' Ook Rhoads en Michie het aangetoon dat die weg van God Jesus se navolgers sal lei na plekke van konfrontasie en verwerping - in beide gevalle duidelike beskrywings van die aard van die na-Pase gemeente in die Markusevangelie.

Omdat Marxsen die opstanding en die wederkoms as een gebeure in die Markusevangelie sien, lê hy vanselfsprekend nie veel klem op die 
Markaanse na-Pase gemeente nie (alhoewel hy die bestaan daarvan implisiet erken). Op grond van die resultate van die narratologiese bestudering van die Evangelie, en veral Markus 13, moet ons egter hierdie na-Pase gemeente as ' $n$ literêre realiteit sien, 'n gemeente wat in navolging van Jesus ook 'n lydende gemeente is.

Wat Markus 16: 7 verder betref, het ons gesien dat Marxsen meen dat dit verwys na die wederkoms van Christus, terwyl Lohmeyer daarenteen beweer het dat dit bloot op 'n verskyning van Jesus aan sy dissipels dui. Petersen (1980: 151-166) ondersteun in hierdie verband vir Lohmeyer. Volgens hom is dit duidelik dat die dissipels se optrede in Markus 13 daarvan getuig dat hulle nou ten volle die identiteit van Jesus verstaan. As ons in ag neem dat die dissipels aan die 'einde' van die Evangelie nog nie werklik verstaan het wie Jesus is nie (en Hom in Mark 14: 50 selfs totaal verlaat het), moet gevra word waar die dissipels in Markus 13 die insig vandaan gekry het. Volgens Petersen slegs by Galilea waar Jesus sy dissipels ontmoet het na sy opstanding.

Alhoewel die standpunt van Petersen na die waarskynlikste lyk, is dit myns insiens nie nodig om 'n keuse daar te stel of Markus 16: 7 op die wederkoms of op 'n werklike ontmoeting van Jesus met sy dissipels dui nie. Hierdie probleem kan eerder opgelos word deur 'n hipotese van antisipasie (as literêre realiteit). Die vroue wat Jesus in Markus volg, word deur Markus regdeur sy Evangelie as getrou beskryf (vgl Malbon 1983: 32-46). Wanneer die dissipels Jesus in Markus 14: 50 verlaat, bly die vroue getrou en is hulle teenwoordig wanneer Jesus aan die kruis sterf en neergelê word. Ook gaan hulle na afloop van die Sabbat om Jesus te salf. Op grond van die opdrag van die engel by die graf (Mark 16: 7) vlug hulle egter. Hierdie onverwagte optrede van die vroue kan as antisipasie in die omgekeerde sin van die woord met betrekking tot die optrede van die dissipels verstaan word. Waar die vroue eens getrou aan Jesus was en insig in sy identiteit gehad het, daar word hulle nou ontrou en vlug; waar die dissipels ontrou was en nie insig in Jesus se identiteit getoon het nie, daar moet die aanbreek van insig nou by hulle veronderstel word. Petersen se tese met betrekking tot die dissipels se insig in Markus 13, sowel as die feit dat Markus 13 as 'n inbedding in die Evangelie vanuit die na-Pase situasie gesien moet word, bevestig immers dat insig by die dissipels aan die einde ( $\mathrm{d} w$ s literêre einde, naamlik Markus 13) van die Evangelie deurgebreek het.

Wat Marxsen se teorie met betrekking tot die Markusevangelie as ' $n$ Galilean Gospel betref, kan tot die volgende gevolgtrekking geraak word: Ons het gesien dat Malbon (vgl afdeling 4.3) aangetoon het dat 
Marxsen nie die Galilea-Jerusalem teëstelling hanteer nie. Ook Rhoads en Michie (vgl afdeling 4.1) handhaaf hierdie standpunt. Myns insiens kan daar egter aan Malbon en Rhoads en Michie in hierdie verband nie gelyk gegee word nie.

Marxsen het nie die Galilea-Jerusalem teëstelling in die Markusevangelie ontken nie. Inteendeel, deur Galilea so sterk te beklemtoon, dui Marxsen beslis aan dat daar ' $n$ teëstelling tussen hierdie twee belangeruimtes in die Markusevangelie bestaan. Die feit dat Marxsen meermale sterk beklemtoon dat Jesus telkens van Jerusalem af terugbeweeg na Galilea voordat Hy die stad finaal binnegaan, versterk hierdie gedagte. Of Galilea die sentrum of fokuspunt van die Markusevangelie is, soos Marxsen beweer, is egter te betwyfel. Op grond van die ideologiese perspektief van die verteller kan die hoofmotief eerder as navolging in lyding beskou word, ' $n$ gevolgtrekking wat bevestig word indien die twee handelingslyne in die Evangelie in ag geneem word. Van Aarde (1985: 272) het duidelik aangetoon dat hierdie twee handelingslyne, asook die feit dat hulle analogies tot mekaar staan, ook in die Matteusevangelie voorkom en dat dit ook daar in 'n noue relasie staan met die ideologiese perspektief van die verteller.

Van lersel sowel as Rhoads en Michie stem in hierdie verband saam met bogenoemde stelling deur die weg (wat navolging impliseer) aan te toon as die sentrale tema van die Evangelie. Volgens Van Iersel funksioneer Galilea wel as belangeruimte in die Evangelie, maar moet dit ook in verband gebring word met ander belangeruimtes in die Evangelie. So beskou Malbon en Rhoads en Michie ook Galilea as een van die belangeruimtes in die Evangelie. Galilea funksioneer dus, volgens hulle, onderliggend as belangeruimte in die Evangelie ter ondersteuning van die hoofmotief in Markus, naamlik die weg.

Daar moet gevolglik met Vorster (1980: 37) saamgestem word oor die rol van Galilea in die Markusevangelie: 'Dat Galilea 'n belangrike rol in Markus se evangelie speel, is duidelik, en dit is waar dat Galilea oorbeklemtoon word om dit in kontras te stel met Jerusalem, die setel van die Joodse godsdiens en die plek waar Jesus gesterf het.'

\section{SLOTOPMERKINGS}

Dit wil dus lyk of 'n narratologiese benadering tot die Markusevangelie (as vertelling) groter perspektiewe open vir die verstaan van die Evangelie as die redaktionsgeschichtliche benadering van Marxsen. Dit 
lyk dus of die stelling korrek is dat die aard van die stof die eksegetiese metode moet bepaal (Van Aarde 1983b: 58).

Die funksie van die plekname Galilea en Jerusalem is duidelik dié van belangeruimte, asook 'n belangrike begronding van die teologiese perspektief van die verteller. Dit is egter nie die sentrale fokuspunt van die Evangelie soos Marxsen beweer het nie, maar dien eerder as begronding van die ideologiese perspektief van navolging in lyding.

Die onderhawige artikel het egter ook aangetoon dat ' $n$ narratologiese ondersoek van die Evangelie nie die basis van Marxsen se tesis met betrekking tot die funksie van Galilea en Jerusalem in die Markusevangelie van die tafel vee nie. Daar kan dus gesê word dat die LohmeyerLightfoot-Marxsen ketting voortgesit word deur 'n narratologiese studie van die Markusevangelie.

\section{Literatuurverwysings}

BARKHUIZEN, JH 1983. Raamwerk vir analise. (Ongepubliseerde diktaat, Departement Grieks, Universiteit van Pretoria).

BEST, E 1977. The role of the disciples in Mark. NTS 23, 377-401.

BLOK, W 1960. Verhaal en lezer. Groningen: Wolters.

BOOMERSHINE, TE 1977. Mark the storyteller: A rhetorical-critical investigation of Mark's passion and resurrection narrative. Michigan: Ann Arbor.

BOOMERSHINE, TE 1981. Mark 16: 8 and the apostolic commission. JBL 100/2, 225-239.

BOOMERSHINE, TE \& BARTHOLOMEW, GL 1981. The narrative technique of Mark 16:

8. JBL 100/2, 213-223.

KELBER, WH 1974. The kingdom of Mark. Philadelphia: Fortress.

KINGSBURY, JD 1979. The Gospel of Mark in current research. Religious Studies Review 5 , $101-107$.

KINGSBURY, JD 1981. Jesus Christ in Matthew, Mark and Luke. Philadelphia: Fortress (Proclamation Commentaries.)

LANSER, SS 1981. The narrative act: Point of view in prose fiction. Princeton: Princeton University Press.

LIGHTFOOT, RH 1938. Locality and doctrine in the gospels. New York: Harper.

LOHMEYER, E 1936. Galiläa und Jerusalem. Göttingen: Vandenhoeck \& Ruprecht.

LOHMEYER, E 1942. Kultus und Evangelium. Göttingen: Vandenhoeck \& Ruprecht.

LOUW, JP 1982. 'n Semiotiese benadering tot diskoersanalise. (Ongepubliseerde diktaat, Departement Grieks, Universiteit van Pretoria).

MALBON, ES 1982. Galilee and Jerusalem: History and literature in Marcan interpretation. CBQ 44, 242-255.

MALBON, ES 1983. Fallible followers: Women and men in the Gospel of Mark. Semeia 28, 29-48.

MARXSEN, W 1959. Der Evangelist Markus: Studien zur Redaktionsgeschichte des Evangeliums. 2. Auflage. Göttingen: Vandenhoeck \& Ruprecht.

MARXSEN, W 1969. Mark the evangelist: Studies on the redaction history of the gospel. Vertaal deur Boyce, I. New York: Abingdon.

MUIR, E 1967. The structure of the novel. London: SCM.

NIDA, EA 1981. Signs sense translation. Pretoria: University of Pretoria.

PERRIN, N 1970. What is redaction-criticism? London: SPCK. 
PETERSEN, NR 1978a. Literary criticism for New Testament critics. Philadelphia: Fortress. PETERSEN, NR 1978b. 'Point of view' in Mark's narrative. Semeia 12, 97-121.

PETERSEN, NR 1980a. The composition of Mark 4: 1-8: 26. HThR 73, 185-217.

PETERSEN, NR 1980b. When is the end not the end? Literary reflections on the ending of Mark's narrative. Interp 34, 151-166.

PRINCE, G 1982. Narratology: The form and function of narrative. Berlin: Mouton.

RHOADS, D \& MICHIE, D 1982. Mark as story: An introduction to the narrative of a gospel. Philadelphia: Fortress.

TANNEHILL, RC 1980. The gospel of Mark as narrative christology. Semeia 16, 57-95.

VAN AARDE, AG 1983a. Die vertellersperspektief-analise: 'n Literatuurteoretiese benadering in die eksegese van die evangelies, in Van Aarde, AG (red), Interpretasiemodelle in evangelienavorsing, 58-83. Pretoria: Universiteit van Pretoria.

VAN AARDE, AG 1983b. Eksegese van vertelmateriaal. (Ongepubliseerde klasaantekeninge, Universiteit van Pretoria).

VAN AARDE, AG 1985a. Plot as mediated through point of view. Matthew 22: 1-14-A case study, in Petzer, \& Hartin, P (eds), A South African perspective on the New Testament: Essays by South African scholars presented to Bruce Manning Metzger during his visit to South Africa in 1985, 62-75. Leiden: Brill.

VAN AARDE, AG 1985b. Vertellersperspektief en die 'temporele' funksie van die Ou Testament in die Matteusevangelie. HTS 41, 272-289.

VAN AARDE, AG 1985c. Die outeurskapvraagstuk van die Johannesevangelie met die oog op interpretasie of resepsie. Skrif en Kerk 6, 45-62.

VANDERMOERE, H 1976. The study of the novel: A structural approach. Leuven: Acco.

VAN ECK, E 1984. Galilea en Jerusalem in die Markusevangelie: 'n Literatuurteoretiese evaluering van die bydrae van W Marxsen. B D-skripsie, Universiteit van Pretoria.

VAN ECK, E 1986. Die funksie van ruimte in die narratologie. HTS 42, 339-349.

VAN IERSEL, BMF 1982a. De betekenis van Marcus vanuit zyn topografische struktuur. TTh 22, 117-138.

VAN IERSEL, BMF 1982b. 'To Galilee' or 'in Galilee' in Mark 14, 28 and 17,7? Ephemerides Theologicae Lovanienses 58, 365-370.

VAN IERSEL, BMF 1983. Locality, structure and meaning in Mark. Linguistica Biblica 53, 45-54.

VENTER, LS 1985. Narratiewe Ruimtes. Tydskrif vir Geesteswetenskappe 25, 19-29.

VORSTER, WS 1980a. Die Evangelie volgens Markus: Inleiding en teologie, in Du Toit, AB (red), Handleiding by die Nuwe Testament, IV. Die Sinoptiese Evangelies en Handelinge: Inleiding en teologie, 109-155. Pretoria: NG Kerkboekhandel.

VORSTER, WS 1980b. Mark: Collector, redactor, author, narrator? IThSA 31, 46-61.

VORSTER, WS 1985. Meaning and reference: The parables of Jesus in Mark 4, in Lategan, $\mathrm{BC}$ \& Vorster, WS, Text and reality: Aspects of reference in Biblical texts. Philadelphia: Fortress.

WELLEK, R \& WARREN, A 1959. Theory of literature. 3rd edition. New York: Harcourt. 